\title{
PELAYANAN PENCATATAN NIKAH DI KUA PASCA PP 48 TAHUN 2014 PADA KUA KABUPATEN LAMPUNG SELATAN
}

\section{THE MARRIAGE REGISTRATION SERVICE AFTER THE ENACTEMENT OF PP 48th 2014 IN KUA LAMPUNG SELATAN REGENCY}

\author{
Marpuah \\ Balai Penelitian dan Pengembangan Agama Jakarta \\ Jl. Rawa Kuning No. 6 Pulo Gebang Cakung Jakarta Timur \\ Email:nyaimarpuah@gmail.com
}

Naskah diterima tanggal 16 juli 2018, Naskah direvisi tanggal 8 Oktober 2018, Naskah disetujui tanggal 5 November 2018

\begin{abstract}
Abstrak
Pelayanan pencatatan nikah merupakan salah satu target reformasi birokrasi di lingkungan Ditjen Bimas Islam yang dilakukan melalui pendekatan sistemik. Hal itu penting mengingat persoalan gratifikasi KUA dan maraknya pelaksanaan nikah sirri di tengah masyarakat akhir-akhir ini menjadikan Kemenag, khususnya Ditjen Bimas Islam harus melaksanakan berbagai upaya menyelesaikan persoalan ini.KUA sebagai lembaga pencatat perkawinan memiliki fungsi penting untuk mewujudkan kemaslahatan umum.Khususnya kepastian dan jaminan perlindungan hukum bagi keluarga Muslim terhadap akibat yang ditimbulkan oleh perkawinan. Selain melayani proses administrasi perkawinan, kerja KUA juga berhubungan langsung dan bahkan hidup bersama dengan tradisi dan norma masyarakat. Penelitian ini dilakukan untuk mengetahui : Bagaimana Pelayanan Pencatatan Nikah di KUA Pasca berlakunya PP 48 tahun 2014 berdasarkan tipologi A, B, C,D1. Apa faktor pendukung dan penghambat dalam pelaksanaan pelayanan pencatatan nikah di KUA. Berdasarkan hasil penelitian dapat diketahui bahwa standar pelayanan pencatatan nikah di KUA Pasca PP 48 tahun 2014 meliputi 6 indikator : a). Prosedur pelayanan, yang dibakukan dan termasuk dengan pengaduan. b). Waktu penyelesaian, yang ditetapkan sejak saat pengajuan permohonan sampai dengan penyelesaian. c). Biaya pelayanan, termasuk rinciannya yang ditetapkan dalam proses pemberian pelayanan. d). Produk pelayanan, yang akan diterima sesuai dengan ketentuan yang telah ditetapkan. e). Sarana dan prasarana yang memadai. f). Kompetensi petugas, yang harus ditetapkan dengan tepat berdasarkan pengetahuan, keahlian, keterampilan, sikap, dan perilaku yang dibutuhkan. Faktor kendalanya: Terbatasnya jumlah ruangan dan SDM yang ada di KUA.
\end{abstract}

Kata Kunci: Pencatatan Nikah di KUA, PP 48 Tahun 2014, Kabupaten Lampung Selatan.

\begin{abstract}
Marriage registration service is one of the targets of bureaucratic reform within the Directorate General of Islamic Community Guidance conducted through a systemic approach. This is important considering the issue of KUA gratification and the rampant implementation of sirri marriage in the midst of society has recently made the Ministry of Religion, especially the Directorate General of Islamic Community Services, have to carry out various efforts to solve this problem. guarantee of legal protection for Muslim families against the consequences of marriage. Apart from serving the marital administration process, KUA's work is also directly related and even lives along with the traditions and norms of society. This research was conducted to find out: How the Marriage Registration Services in KUA After the enactment of PP 48 of 2014 based on typologies $A, B, C, D 1$. What are the supporting and inhibiting factors in the implementation of marriage registration services at KUA. Based on the results of the study it can be seen that the standard of marriage registration services at KUA Post PP 48 of 2014 includes 6 indicators: a). Service procedures, which are standardized and include complaints. b). Settlement time, which is determined from the time the application is submitted to completion. c). Service fees, including details specified in the service delivery process. d). Service products, which will be accepted in accordance with the stipulated provisions. e). Facilities and infrastructure, which are adequate. f). Officer competency, which must be determined appropriately based on the knowledge, expertise, skills, attitudes, and behaviors needed. Obstacle factors: Limited number of rooms and human resources in the KUA.
\end{abstract}

Keywords: Marriage Registration Services at KUA, Post PP 48 Year 2014, South Lampung Regency. 


\section{PENDAHULUAN}

B erdasarkan Undang-Undang No. 1 Tahun 1974 tentang Perkawinan disebutkan bahwa perkawinan yang sah dilakukan menurut hukum masing-masing agamanya dan kepercayaannya.Kemudian disebutkan bahwa tiap-tiap perkawinan dicatat menurut peraturan perundang-undangan yang berlaku. Hal ini menunjukkan bahwa titik berat sahnya suatu perkawinan adalah pada sahnya perkawinan itu menurut hukum agama dan ketentuan yang mengharuskan perkawinan itu untuk dicatat. Setiap orang Islam yang akan melangsungkan pernikahan menurut hukum Islam dan dilaksanakan di hadapan pejabat yang berwenang. Maka pejabat tersebut berkewajiban mengawasi dan menyaksikan serta melakukan pencatatan terhadap peristiwa pernikahan tersebut.

Berdasarkan Keputusan Menteri Agama Nomor 47 Tahun 2004 yang telah ditetapkan, bentuk berbagai formulir yang dikaitkan dengan pencatatan nikah, dan rujuk serta pendaftaran cerai. Dalam suatu pencatatan sekecil apapun kesalahan hendaknya dihindari khususnya dalam pembuatan akta nikah dan buku nikah serta buku pencatatan rujuk dan kutipannya. Apabila terjadi kesalahan dalam pembuatan akta, akan menimbulkan dampak negatif, menurunnya kepercayaan masyarakat kepada KUA Kecamatan, disamping itu akan menimbulkan masalah di kemudian hari. Untuk menjaga hal-hal tersebut di atas, maka disusunlah petunjuk pengisian formulir nikah untuk dapat dipedomani oleh para penghulu dan pejabat teknis dengan sebaik-baiknya.(Surat Edaran Dirjen Bimas Islam dan Penyelenggaraan Haji No: DJ.I/1/ PW.01/1487/2005 tentang Petunjuk Pengisian Formulir Nikah dan Rujuk).

PP Nomor 48 Tahun 2014 adalah perubahan atas PP Nomor 47 Tahun 2004 tentang Tarif Atas Jenis Penerimaan Negara Bukan Pajak (PNBP) yang berlaku pada Departemen Agama. Terdapat beberapa tujuan kenapa PP Nomor 47 Tahun 2004 ini dirubah oleh PP Nomor 48 Tahun 2014. Di antaranya, adalah: (1) Semangat menjadikan KUA yang berintegritas dan terbebas dari gratifikasi; (2) Memperjelas keuangan yang dibayarkan masyarakat untuk biaya pernikahan; (3) Mengakomodir kepentingan, kompensasi, dan penghargaan kepada para penghulu yang menghadiri pernikahan di luar kantor atau luar jam kantor. Tiga faktor tersebut yang tidak diakomodir oleh PP Nomor 47
Tahun 2004 yang akan dicermati adalah : Besaran Nominal, Biaya Pencatatan Nikah VS Biaya Nikah, Cara Penerimaan, Penggunaan Biaya NR.

Perubahan yang ditetapkan di dalam PP Nomor 48 Tahun 2014 di antaranya yaitu adanya multi tarif yang dikenakan kepada masyarakat yang akan menikah. Di dalam PP Nomor 48 Tahun 2014 disebutkan pada pasal 6: 1) Setiap warga negara yang melaksanakan nikah atau rujuk di Kantor Urusan Agama Kecamatan atau di luar Kantor Urusan Agama Kecamatan tidak dikenakan biaya pencatatan nikah atau rujuk. (2) Dalam hal nikah atau rujuk dilaksanakan di luar Kantor Urusan Agama Kecamatan dikenakan biaya transportasi dan jasa profesi sebagai penerimaan dari Kantor Urusan Agama Kecamatan; (3) Terhadap warga negara yang tidak mampu secara ekonomi dan/atau korban bencana yang melaksanakan nikah atau rujuk di luar Kantor Urusan Agama Kecamatan sebagaimana dimaksud pada ayat (2) dapat dikenakan tarif Rp 0,00 (nol rupiah); (4) Ketentuan lebih lanjut mengenai syarat dan tata cara untuk dapat dikenakan tarif Rp0,00 (nol rupiah) kepada warga negara yang tidak mampu secara ekonomi dan/atau korban bencana yang melaksanakan nikah atau rujuk di luar Kantor Urusan Agama Kecamatan sebagaimana dimaksud pada ayat (3) diatur dengan Peraturan Menteri Agama setelah berkoordinasi dengan Menteri Keuangan.(PP 48 Tahun 2014 dalam Khoirul Anwar, SHI, Penghulu KUA Saketi Pandeglang Banten).

Perubahan besar ini dapat dimaklumi, karena adanya perubahan penggunaannya.Perubahan penggunaan ini dapat dilihat dari PMA Nomor 24 Tahun 2014 yang merubah PMA Nomor 71 Tahun 2009.Dari judul PMA itu sendiri sudah dapat diketahui bahwa adanya transformasi (perubahan) dari "biaya pencatatan nikah dan rujuk" menjadi "biaya nikah danrujuk".Di dalam PMA Nomor 24 Tahun 2014 yang baru adalah turunan dari PP Nomor 48 Tahun 2014 dapat diketahui bahwa tidak ada lagi biaya pencatatan pernikahan atau rujuk.Hal itu tercantum di dalam pasal 6 ayat (1).

Dalam PP tersebut dijelaskan perubahanperubahan apa saja yang menyangkut Penerimaan Negara Bukan Pajak (PNBP) pada Departemen Agama diantaranya adalah biaya pencatatan perkawinan di Kantor Urusan Agama (KUA) yang semula dikenakan biaya sebesar Rp. 30.000,00 per peristiwa menjadi dibebaskan apabila melakukan Proses Pencatatan Nikah di Kantor Urusan Agama. Namun apabila proses Pencatatan Nikah 
tersebut ingin dilakukan di luar Kantor Urusan Agama (bedolan) maka dikenakan biaya sebesar Rp. $600.000,00$ per peristiwa. Biaya tersebut difungsikan untuk biaya transportasi penghulu dan hal-hal yang bersifat administratif lainnya sebagai bentuk penerimaan Kantor Urusan Agama Kecamatan.

Kantor Urusan Agama adalah unit kerja terdepan yang melaksanakan sebagian tugas pemerintah di bidang agama Islam.Lingkup kerja KUA adalah berada di wilayah tingkat Kecamatan. Hal ini sebagaimana ketentuan pasal 1 (1) PMA Nomor 11 Tahun 2007 tentang Pencatatan Nikah. Dalam pasal tersebut menyebutkan bahwa Kantor Urusan Agama Kecamatan yang selanjutnya disebut KUA adalah instansi Departemen Agama yang bertugas melaksanakan sebagian tugas Kantor Departemen Agama Kabupaten/Kota di Bidang Urusan Agama Islam dalam wilayah Kecamatan. Institusi Kantor Urusan Agama berdasarkan fakta sejarah sebenarnya telah ada sejak jaman kerajaan dan penjajahan, hanya sebutan istilah saja yang berbeda. Istilah pemangku Kantor Urusan Agama ini pada masa kerajaan Mataram Islam dikenal dengan istilah reh-penghulon, yang memiliki otoritas dalam menjalankan hukum Islam di lingkungan kerajaan atau pusat pemerintahan dan sampai pada tingkat paling bawah yaitu kewedanaan atau kecamatan (Kuntowijoyo, 1991: 125).

KUA sebagai etalase Kemenag terus mendapat perhatian, termasuk keinginan mengangkat citra baru KUA sebagai lembaga yang bersih dan melayani. Berbagai kebijakan pun telah diambil, seperti pembangunan fisik terkait rehabilitasi sarpras KUA, pembangunan gedung baru, modernisasi layanan administrasi berbasis IT, dan lain-lain. Semua itu bertujuan untuk mengembangkan peran Kemenag dan mengembalikan citra sebagai pelayanan umat (khadimul ummah).Terkait upaya menghindari gratifikasi, Ditjen Bimas Islam mengeluarkan penjelasan tentang alur pelayanan nikah sesuai dengan yang diatur dalam PP No 48 Tahun 2014 tentang Perubahan atas Peraturan Pemerintah Nomor 47 tahun 2004 tentang Tarif Atas Jenis Penerimaan Negara Bukan Pajak (PNBP).Machasin mengatakan, PP 48/2014 mengatur bahwa biaya pernikahan hanya terbagi menjadi dua, yaitu pertama gratis atau nol rupiah jika proses nikah dilakukan pada jam kerja di KUA; dan kedua dikenakan biaya Rp. 600.000 ;jika nikah dilakukan di luar KUA dan atau di luar hari dan jam
kerja."Tidak ada biaya lain yang harus dikeluarkan oleh calon pengantin di luar yang sudah ditentukan oleh peraturan tersebut. Pungutan biaya di luar yang sudah ditentukan bisa dimasukan dalam kategori gratifikasi," tegas Machasin.

Ia menjelaskan bahwa pelayanan pencatatan nikah merupakan salah satu target reformasi birokrasi di lingkungan Ditjen Bimas Islam yang dilakukan melalui pendekatan sistemik. Hal itu penting mengingat persoalan gratifikasi KUA dan maraknya pelaksanaan nikah sirri di tengah masyarakat akhir-akhir ini menjadikan Kemenag, khususnya Ditjen Bimas Islam harus melaksanakan berbagai upaya menyelesaikan persoalan ini. Menurut Machasin, KUA sebagai lembaga pencatat perkawinan memiliki fungsi penting untuk mewujudkan kemaslahatan umum. Khususnya kepastian dan jaminan perlindungan hukum bagi keluarga Muslim terhadap akibat yang ditimbulkan oleh perkawinan. Selain melayani proses administrasi perkawinan, kerja KUA juga berhubungan langsung dan bahkan hidup bersama dengan tradisi dan norma masyarakat.

Kabupaten Lampung Selatan secara geografis terletak pada 1052 - 1050452 Bujur Timur dan 5015 - 62 Lintang Selatan, dengan batas wilayahnya : Sebelah Barat berbatasan dengan wilayah Bandar Lampung dan Kabupaten Pesawaran. Sebelah Timur berbatasan dengan Laut Jawa.Sebelah Utara berbatasan dengan wilayah Kabupaten Lampung Tengah dan Lampung Timur.Sebelah Selatan berbatasan dengan Selat Sunda.Kabupaten Lampung Selatan yang beribukota di Kalianda memiliki luas 331.904 hektar yang terbagi dalam 251 Desa/ Kelurahan dan 17 Kecamatan.

Berdasarkan data yang ada penduduk Kabupaten Lampung Selatan secara garis besar dapat digolongkan menjadi dua bagian yaitu penduduk asli Lampung dan penduduk pendatang. Penduduk asli khususnya sub suku Lampung Peminggir umumnya berkediaman di sepanjang pesisir pantai. Penduduk sub suku lainnya tersebar di seluruh wilayah Kabupaten Lampung Selatan. Pendudukpendatang yang berdomisili di Kabupaten Lampung Selatan terdiri dari bermacam-macam suku dari berbagai daerah di Indonesia seperti Jawa Barat, Jawa Tengah, Jawa Timur, Bali, Sulawesi, Sumatera Selatan, Sumatera Barat, Sumatera Utara dan Aceh. Dari semua suku pendatang tersebut jumlah terbesar adalah pendatang dari Pulau Jawa.Besarnya penduduk yang berasal dari Pulau Jawa dimungkinkan oleh adanya kolonisasi pada 
zaman penjajahan Belanda dan dilanjutkan dengan transmigrasi pada masa setelah kemerdekaan, disamping perpindahan penduduk secara swakarsa dan spontan.Beragamnya etnis penduduk di Kabupaten Lampung Selatan mungkin juga disebabkan karena KabupatenLampung Selatan sebagian besar adalah wilayah pantai sehingga banyak nelayan yang bersandar dan menetap. Adapun jumlah penduduk di Kabupaten Lampung Selatan berdasarkan Agama : Agama Islam dengan jumlah 873.654 orang, Kristen 12.829 orang, Katolik 5.598 orang, Hindu 15.014 orang, dan Budha 1.116 orang, Konghucu 34 orang, jumlah seluruhnya 912.490 orang (Sumber data : BPS2010). Dalam hal ini pentingnya dilakukan penelitian : untuk mengetahui : Bagaimana kondisi KUA di wilayah Provinsi Lampung Pasca PP 48 Tahun 2014. Untuk mengetahui tipologi KUA dalam kategori tipologi A B C D1 di wilayah Provinsi Lampung.Bagaimana ketersediaan pedoman pelayanan dalam bentuk prosedur operasional standar (SOP) di KUA. Apa faktor pendukung dan penghambat dalam pelaksanaan pelayanan pencatatan nikah di KUA, pasca berlakunya PP 48 tahun 2014.

\section{Tinjauan Pustaka}

\section{Standar Kualitas Pelayanan Publik}

Setiap penyelenggara pelayanan publik harus memiliki standar pelayanan dan dipublikasikan sebagai jaminan adanya kepastian bagi penerima pelayanan. Standar pelayanan merupakan ukuran yang dibakukan dalam penyelenggaraan pelayanan publik yang wajib ditaati oleh pemberi dan atau penerima pelayanan. Adapun standar pelayanan publik menurut Keputusan Menpan Nomor 63 tahun 2003 yaitu meliputi : a).Prosedur pelayanan, yang dibakukan dan termasuk dengan pengaduan. b).Waktu penyelesaian, yang ditetapkan sejak saat pengajuan permohonan sampai dengan penyelesaian. c).Biaya pelayanan, termasuk rinciannya yang ditetapkan dalam proses pemberian pelayanan. d).Produk pelayanan, yang akan diterima sesuai dengan ketentuan yang telah ditetapkan. e).Sarana dan prasarana, yang memadai. f).Kompetensi petugas, yang harus ditetapkan dengan tepat berdasarkan pengetahuan, keahlian, keterampilan, sikap, dan perilaku yang dibutuhkan. Berdasarkan Kemenpan Nomor 63 tahun 2003 dijelaskan tentang 6 indikator standar pelayanan publik. Indikator-indikator itu meliputi prosedur pelayanan, waktu penyelesaian, biaya pelayanan, produk pelayanan, sarana prasarana dan kompetensi petugas pemberi pelayanan publik.

PNBP (Penerimaan Negara Bukan Pajak) di Kementerian Agama adalah seluruh penerimaan Pemerintah pusat yang tidak berasal dari penerimaan perpajakan Penerimaan Negara Bukan pajak yang berlaku pada Kementerian Agama.Salah satunya adalah Penerimaan dari pencatatan nikah dan rujuk. Pada tahun 2014 Pemerintah mengeluarkan Peraturan baru tentang PNBP yang berlaku di Kementerian Agama,yaitu Peraturan Pemerintah Nomor 48 Tahun 2014, yaitu Masyarakat tidak dikenai biaya pencatatan nikah atau rujuk, jika nikah dilakukan di KUA. Nikah atau rujuk di luar KUA dikenai biaya transportasi dan jasa profesi sebesar Rp. 600.000, dan khusus bagi warga negara yang kurang mampu secara ekonomi dan atau korban bencana yang melaksanakan akad nikah di luar KUA dapat dikenai tarif Rp. 0,00 dengan syarat dan tata cara yang diatur dalam Peraturan Menteri Agama (PMA) Nomor 46 Tahun 2014 tentang, Pengelolaan Penerimaan Negara Bukan Pajak Atas Biaya Nikah Atau Rujuk di Luar Kantor Urusan Agama Kecamatan.

\section{Kesadaran Hukum}

Kesadaran hukum akan terwujud apabila ada indikator pengetahuan hukum, pemahaman hukum, sikap hukum, dan prilaku hukum yang patuh terhadap hukum. Indikator indikator inilah yang dapat dijadikan tolak ukur dari kesadaran hukum, karena jika pengetahuan hukum, sikap hukum, dan prilaku hukumnya rendah maka kesadaran hukumnya rendah atau sebaliknya. Kesadaran hukum yang rendah atau tinggi pada masyarakat mempengaruhi pelaksanaan hukum. Kesadaran hukum yang rendah akan menjadi kendala dalam pelaksanaan hukum, baik berupa tingginya tingkat pelanggaran hukum maupun kurang partisipasinya masyarakat dalam pelaksanaan hukum.

\section{Berlakunya Hukum Di Masyarakat}

Tentang berlakunya hukum menurut Soejono Soekanto dapat dibedakan atas tiga hal, yaitu berlakunya secara filosofis, yuridis dan sosiologis. Berlakunya hukum secara filosofis berarti bahwa hukum tersebut sesuai cita-cita hukum, sebagai nilai positif yang tertinggi.Berlakunya hukum secara yuridis, dijumpai anggapan-anggapan sebagai berikut yaitu Hans Kelsen, yang menyatakan bahwa kaidah hukum mempunyai kelakuan yuridis, apabila penentuannya berdasarkan kaidah yang lebih tinggi tingkatannya. Dan menurut W. 
Zevenbergen, menyatakan bahwa suatu kaidah hukum mempunyai kelakuan yuridis, jikalau kaidah tersebut terbentuk menurut cara yang ditetapkan. Berlakunya hukum secara sosiologis intinya adalah "efektivitas hukum.Yaitu apabila kaidah hukum tersebut efektif. Artinya kaidah itu dapat dipaksakan berlakunya oleh penguasa walaupun tidak diterima oleh warga masyarakat (teori kekuasaan), atau kaidah itu berlaku karena adanya pengakuan dari masyarkat.

\section{METODE PENELITIAN}

Metode penelitian pada dasarnya merupakan cara ilmiah untuk mendapatkan data dengan tujuan dan kegunaan tertentu. Tujuan dari metode penelitian adalah dapat membantu peneliti dalam menghasilkan penelitian yang objektif, dan dapat dipertanggung jawabkan berdasarkan atas data yang diperoleh (Sugiyono, 2011: 1\&6). Penelitian ini menggunakan metode deskriptif dengan pendekatan kualitatif.Metode pendekatan kualitatif digunakan dalam metode penelitian ini karena data yang dihasilkan dalam penelitian ini berupa katakata tertulis dan lisan. Menurut Moleong (2007: 3) menyatakan bahwa metode kualitatif sebagai prosedur penelitian yang menghasilkan data deskriptif berupa kata-kata tertulis atau lisan dari orang-orang yang perilakunya diamati.

Lokasi penelitian dilakukan di Provinsi Lampung, stresingnya adalah Kabupaten Lampung Selatan yang termasuk dalam kategori tipologi A B C D1 di KUA Kecamatan.Data dalam penelitian terdiri dari data primer dan data sekunder. 1. Data Primer, yaitu data yang diperoleh dari informan secara langsung dengan cara observasi dan wawancara. Data primer merupakan narasumber utama. Narasumber itu sendiri adalah orang-orang yang benar-benar tahu dan terlibat dengan implementasi kebijakan yang telah dijalankan.Pemilihan informan atau narasumber sebagai sumber data atau informan dalam penelitian ini berdasarkan atas subjek yang menguasai permasalahan, memiliki data dan bersedia memberikan informasi yang lengkap dan akurat. 2. Data Sekunder, yaitu data yang diperoleh secara tidak langsung. Data ini diperoleh dari studi kepustakaan, yaitu metode pengumpulan data dengan melihatbeberapa literature, antara lain: catatan, buku, dokumen yang ada hubungannya dengan penelitian tersebut. Data sekunder dalam penelitian ini berupa dokumen dari Kantor Urusan Agama Kecamatan, dari Kanwil Kemenag Provinsi, dan dari Kan.Kemenag Kabupaten Lampung Selatan.

Teknik pengumpulan data melalui a). wawancara mendalam kepada key informan : Kabid Urais dan Kasi Pemberdayaan KUA Kanwil Kemenag Provinsi, Kepala Kandepag dan Bimas Islam Kabupaten Lampung Selatan. Kepala KUA (Natar, Merbau Mataram,Tanjung Sari, dan Rajabasa) sebagai obyek penelitian, dan Penghulu KUA, serta TU nya yang terkait dengan kegiatan penelitian ini. b). Observasi. Observasi dilakukan dalam proses pelayanan pencatatan Nikah di KUA atau pun di luar KUA. c). Dokumentasi. Dokumentasi sebagai bahan kajian literatur yang terkait dengan kegiatan penelitian ini.

Teknik Pengolahan data. Berdasarkan hasil penelitian baik itu data primer maupun data skunder, data tersebut diklasifikasikan dan diinterpretasikan dengan dianalisis secara diskriptif kualitatif. Dalam analisa data kualitatif yaitu penarikan kesimpulan dan verifikasi.

\section{PEMBAHASAN \\ Peristiwa Nikah di KUA Kabupaten lampung Selatan}

Kabupaten Lampung Selatan adalah salah satu dari jumlah 14 Kabupaten/Kota yang memiliki tipologi KUA :A B C D1. Kabupaten Lampung Selatan terdiri dari 17 Kecamatan, dari jumlah Kecamatan tersebut terdiri dari 15 KUA Kecamatan yang sudah definitif, dan 2 KUA yang belum definitif yaitu Kecamatan Bakauhuni dan Kecamatan Way panji. Dilihat dari usia catin di KUA Kabupaten Lampung Selatan pada umumnya usia pernikahan 16 tahun - 19 tahun untuk catin perempuan, dan 19 tahun -21 tahun untuk catin laki-laki. Mata pencaharian mereka : sebagai buruh tani, buruh tukang kebun kelapa sawit, tukang bangunan, PNS, biraswasta (pedagang), TNI, Polri. 
Tabel : Peristiwa Nikah di KUA berdasarkan tipologi A, B, C, D1 di Kabupaten Lampung Selatan

\begin{tabular}{|c|c|c|c|c|c|}
\hline \multirow{2}{*}{ No } & \multirow{2}{*}{ Nama KUA } & \multicolumn{2}{|c|}{ Peristiwa Nikah/Th } & \multirow{2}{*}{ Tipologi KUA } & \multirow{2}{*}{ Keterangan } \\
\hline & & 2015 & 2016 & & \\
\hline 1. & KUA Natar & 1800 & 1500 & A & Akhir juli 2016 \\
\hline 2. & KUA Merbau Mataram & 500 & 297 & B & Akhir juli 2016 \\
\hline 3. & KUA Tanjung Sari & 227 & 157 & $\mathrm{C}$ & Akhir juli 2016 \\
\hline 4. & KUA Rajabasa & 218 & 126 & $\mathrm{D} 1$ & Akhir juli 2016 \\
\hline & Jumlah N & 2.745 & 2080 & & Akhir juli 2016 \\
\hline
\end{tabular}

Program Reformasi birokrasi telah membuka warna baru dalam bentuk pelayanan publik di Provinsi Lampung. Berbagai instansi pemerintahan telah (sedang) melakukan pembenahan diberbagai sektor yang selama ini menjadi titik lemah bagi pelayanan publik.Salah satunya adalahKementerian Agamayang kini terus berupaya untuk berbenah dalam layanan pernikahan di KUA.Sebagai ujung tombak layanan publik Kementerian Agama ditingkat terbawah, KUA pun segera(telah)berbenah menyesuaikan diri dengan berbagai perubahan yang menjadi keniscayaan reformasi birokrasi.Salah satu perubahan mendasar adalah bentuk baru pelayanan dibidang perkawinan, terutama pasca terbitnya PP No 48 Tahun 2014 Tentang perubahan atas Peraturan Pemerintah No 47 Tahun 2004 tentang tarif atas jenis Penerimaan Negara Bukan Pajak. Kemudian diikuti dengan terbitnya PMA No.24 Tahun 2014 Tentang Pengelolaan Penerimaan Negara bukan Pajak Atas Biaya Nikah dan rujuk di luar Kantor Urusan Agama Kecamatan.

Selama ini KUA telah mendapat stigma yang cukup kuat ditengah masyarakat sebagai lembaga yang rentan terhadap praktik pungli dan gratifikasi.Bahkan dalam beberapa tahun telah mendapat perhatian serius dari lembaga penegak hukum, seperti KPK dan Kejaksaan.Indikasinya adalah dijadikannya salah seorang aparatur KUA di Kediri sebagai terpidana kasus korupsi (pungutan liar).Inilah yang kemudian mendorong pemangku kebijakan ditingkat pusat untuk mencari formula ideal guna melakukan reformasi dibidang pelayanan publik untuk memperbaiki citraKUA. Meski kebijakan baru melalui penerbitan PP 48 2014 berimplikasi pada soal-soal teknis, namun hal ini mendapat dorongan kuat dari penghulu seIndonesia, khususnya yang tergabung dalam APRI. Terbitnya PP 482014 tersebut terdapat beberapa potensi masalah yang perlu disikapi bersama agar ke depan pelaksanaan layanan betul-betul semakin meningkat:
Pertamamasalah persepsi.Aparatur penegak hukum seharusnya bisa membuka mata bahwa ada banyak pihak terkait dalam perkawinan, disana ada peran dari desa atau kelurahan, juga pihak kecamatan.Artinya masalah pernikahan tidak hanya menjadi domain Kementerian Agama, dalam hal ini Kantor Urusan Agama.Ketika Kementerian Agama telah berbenah diri dengan mengeluarkan peraturan baru yang memiliki spirit yang baru, maka sudah selayaknya diikuti dengan aksi serupa oleh institusi yang membawahi desa/kelurahan.Fakta dilapangan telah berbicara, meskipun aturan di PP No 2014/48 sudah jelas, terkait dengan biaya nikah, namun biaya tersebut hanya berlaku di KUA. Sementara sebelum ke KUA, prosedur perkawinan harus melibatkan pihak lain yaitu adanya pengantar dari RT, RW, hingga ke tingkat desa/kelurahan, dan dalam kasus tertentu, hingga tingkat kecamatan.

Proses yang lumayan panjang tersebut faktanya memerlukan waktu dan juga biaya. Sementara tidak ada aturan yang pasti mengenai waktu dan juga biaya yang berlaku untuk melakukan proses tersebut. Sehingga timbul pemahaman di masyarakat, bahwa biaya tersebut adalah biaya yang juga melibatkan KUA.Belum lagi hal ini juga melibatkan P3N yang tidak bisa dikontrol oleh pihak KUA jika terjadi pungutan di luar ketentuan. Bisa jadi, pada saat riset integritas dilakukan pihak lain (termasuk KPK sekalipun) tentang biaya nikah, maka ada kemungkinan biaya yang disebutkan oleh masyarakat akan melebihi ketentuan yang disebutkan PP 48 2014. Sudah bisa ditebak, bahwa hasilnya akan sangat mempengaruhi citra KUA. Inilah problem yang terjadi dilapangan.

Kedua adalah infrastruktur Kantor Urusan Agama.Faktayang terjadi pasca terbitnya aturan baru tentang perkawinan, bahwa masyarakat mayoritas memilih untuk melaksanakan perkawinan di luar KUA. Hal tersebut bisa dimaklumi mengingat ada margin yang cukup besar dari segi sarana dan prasarana KUA, antara nikah di KUA pada jam 
kantor dan nikah diluar KUA baik pada jam kantor ataupun jam luar kantor. Contoh kecil, di KUA Kecamatan Natar Kabupaten Lampung Selatan, jumlah pernikahan pada tahun 2015 dan tahun 2016, diratakan mencapai 150 peristiwa nikah per bulannya, $65 \%$ dilaksanakan di luar kantor, dan 35 $\%$ dilaksanakan di Kantor pada jam kerja. Padahal pasca berlakunya PP 48 tahun 2014, ada ketentuan jika nikah di luar kantor dikenakan biaya Rp. 600.000, sedangkan nikah di KUA tidak dikenakan biaya. Hal ini diketahui karena ada keterkaitan dengan kesediaan fasilitas dalam pelayanan nikah di KUA.Selain terkait dengan jarak tempuh antara catin kehendak nikah dengan KUA setempat, seperti Desa Tegineneng Kecamatan Natar dengan jarak tempuh $30 \mathrm{~km}$ lebih.Juga terkait dengan kekentalan adat budaya lokalnya "piil pesenggiri" maupun adat budaya jawa sebagai transmigran di Kabupaten Lampung Selatan.

Namun walaupun kenyataan di lapangan seperti itu, akan tetapi sarana dan prasarana dalam hal ruang lingkup pernikahan masih diperlukan adanyapenyediaan infrastruktur kantor yang representatif dan layak. Sehingga masyarakat merasa nyaman untuk melaksanakan pernikahan di Kantor.Pelayanan publik di KUA yang berbasis jasa, dan untuk menghasilkan pelayanan yang primatidak hanya Sumber Daya Manusianya yang dibangun, infrastruktur yang baik juga menjadi salah satu faktor penentu. Justru tempat yang baik akan menjadi kesan pertama bagi masyarakat dalam rangka memenuhi kebutuhan mereka mendapat pelayanan.

Ketiga, masih adanya potensi "gratifikasi". Selama ini para penghulu dianggap sebagai pihak yang sering disorot dengan dugaan gratifikasi. Sudah menjadi hal lumrah jika setelah menghadiri pernikahan, mereka mendapat "Tanda Terima kasih" dari pihak pengantin.Inilah yang disorot oleh inspektorat jenderal Kementerian Agama RI, bahkan oleh KPK.Sehingga kemudian menjadi salah satu motif diterbitkannya PP No.48 tahun 2014.Potensi gratifikasi sangat dimungkinkan terjadi.Mengingat sampai sekarang walaupun sudah ada petunjuk teknis pelaksanaan PP 48 tersebut, khususnya peraturan Dirjen Bimas Islam. Namun dalam hal pencairan dana PNBP yang telah ditetapkan untuk dialokasikan ke KUA masih terlambat dalam pencairannya di daerah. Selama ini dana PNBP dicairkan dari pusat 3-4 bulan sekali. Para penghulu sangat membutuhkan kepastian terkait cairnya dana PNBP.
Dikalangan penghulu isu itu menjadi topik yang hangat diperbincangkan. Proses yang terlalu lama terkait pencairan hak-hak mereka menjadikan mereka "galau". Ketika kewajiban telah ditunaikan, maka sudah selayaknya hak-hak pun diperhatikan dengan segera. Selama ini para penghulu, sebagai pelaksana teknis perkawinan dilapangan telah beradaptasi menyesuaikan diri dengan aturan baru tersebut dan menolak berbagai "gratifikasi" dari masyarakat. Namun dengan berlarutnya aturan yang tak kunjung turun, maka timbul kekhawatiran akanterjadi kembali gratifikasi. Karenanya dalam hal ini menjadi penting untuk diperhatikan dan disikapi oleh pihak-pihak yang berwenang.

\section{Pelayanan Pencatatan Nikah di Kantor Urusan Agama Kecamatan}

Visi Kantor Urusan Agama Kecamtan adalah: "Profesional dan amanah dalam membina keluarga sakinah dan pemberdayaan umat". Pelayanan pencatatan nikah ini merupakan salah satu bentuk pelayanan yang diberikan oleh Kantor Urusan Agama (KUA) kepada masyarakat yang akan melakukan pernikahan khususnya untuk masyarakat muslim pada masing-masing Kecamatan. Kualitas pelayanan pencatatan nikah yang diberikan oleh Kantor Urusan Agama (KUA) dalam hal ini adalah KUA yang berada di Kecamatan dapat dilihat melalui beberapaindikator pelayanan dari Keputusan Menpan No.63 Tahun 2003 mengenai pedoman umum penyelenggaraan pelayanan publik yang meliputi:

\section{Prosedur Pelayanan}

Prosedur pelayanan merupakan tahapan-tahapan atau proses dalam penyelenggaraan pelayanan. Dalam hal ini prosedur pelayanan pencatatan nikah melibatkan 2 pihak utama yaitu pemohon dan pihak KUA Kecamatan itu sendiri. Mengenai prosedur yang wajib dipenuhi oleh pemohon sudah terdapat sejak lama pada Peraturan Menteri Agama No. 11 Tahun 2007 tentang Pencatatan Nikah. Dalam PMA tersebut sudah dijelaskan secara rinci mengenai prosedur pendaftaran sampai pelaksanaan akad dan penyerahan produk pelayanan. Dari hasil penelitian yang telah dilakukan kepada pihak KUA Kecamatan itu sendiri, dan juga kepada masyarakat selaku penerima layanan diketahui, bahwa sosialisasi tentang prosedur pelayanan pencatatan nikah yang diberikan KUA sudah dilakukan dengan cukup baik oleh pihak KUA Kecamatan.Sehingga 
masyarakat banyak yang sudah paham dengan prosedur-prosedur untuk mendapatkan pelayanan pencatatan nikah. Namun, saat mengajukan pendaftaran kehendak nikah masih ada yang didampingi oleh pihak keluarganya/RT setempat dari masing-masing wilayahdemi kelancaran proses pemenuhan berkas-berkas yang diperlukan.

KUA Kecamatan sebagai obyek sasaran penelitian, juga sudah melengkapi informasi mengenai prosedur pelayanan dengan memberikan gambar alur prosedur pelayanan pencatatan nikah di dekat pintu masuk KUA Kecamatan. Demikian pula dengan sosialisasi langsung yang diberikan oleh petugas KUA dengan menjawab segala pertanyaan mengenai prosedur pelayanan pencatatan nikah dengan jelas dan ramah. Mengenai alur prosedur pelayanan yang telah diatur, masyarakat selaku penerima layanan menyatakan bahwa prosedur yang ada tidak terlalu rumit dan cukup mudah untuk dipenuhi demi kelancaran proses pencatatan nikahnya. Demikian dapat dinyatakan bahwa prosedur pelayanan pencatatan nikah yang ada di Kantor Urusan Agama (KUA) Kecamatan sudah sesuai dengan ketentuan prosedur pelayanan yang telah ditetapkan.Seperti Standar Pelayanan Prosedur (SOP) tentang prosedur Kehendak Nikah, Prosedur Pembiayaan, Prosedur Suscaten, dan prosedur perolehan Akta Nikah.

\section{Waktu Penyelesaian}

Waktu penyelesaian adalah waktu yang telah ditetapkan dalam pemberian pelayanan dari awal sampai dengan proses akhir pelayanan. Dimana dalam pelayanan yang diberikan oleh KUA ini setiap harinya dimulai pukul 07.00 pagi sampai dengan pukul 16.00 sore. Hal tersebut sudah sesuai dengan temuan yang ada dilapangan, dimana masyarakat juga sudah mengetahui tentang hal tersebut khususnya masyarakat yang akan melangsungkan semua proses pencatatan nikahnya di balai nikah KUA Kecamatan. Kemudian untuk waktu penyelesaian secara khusus mengenai pencatatan nikah sendiri juga sudah sesuai dengan PP Nomor 9 Tahun 1975 pasal 3 ayat 2, yaitu: "Pemberitahuan tersebut dalam ayat (1) dilakukan sekurangkurangnya 10 (sepuluh) hari kerja sebelum perkawinan dilangsungkan".Dimulai dari proses pengajuan kehendak nikah yang secara prosedur wajib dilaksanakan minimal 10 (sepuluh) hari kerja. Sebelum dilaksanakannya proses akad nikah sampai diterbitkannya produk dari pelayanan pencatatan nikah tersebut dalam bentuk buku nikah. Hal tersebut dikarenakan agar pihak KUA dapat melihat kelengkapan dan kecocokan berkas- berkas yang diajukan, sehingga tidak terjadi kesalahan cetak dan penulisan yang akan dicantumkan pada produk pelayanan. Dalam hal ini bahwa KUA Kecamatan sudah dapat menyelesaikan pelayanan pencatatan nikahnya sesuai dengan ketentuan yang ada.

\section{Biaya Pelayanan}

Biaya pelayanan merupakan tarif yang dibebankan kepada masyarakat untuk dapat memperoleh pelayanan dari instansi yang dalam hal ini adalah Kantor Urusan Agama (KUA) Kecamatan.Khusus untuk pelayanan pencatatan nikah, tarif yang dibebankan kepada masyarakat mengalami perubahan pada Tahun 2014, dikarenakan adanya indikasi pungutan liar yang dilakukan oleh pihak KUA. Besaran biaya pelayanan pencatatan nikah sebelum adanya perubahan telah diatur dalam PP Nomor 47 Tahun 2004. Dimana dalam PP tersebut jumlah nominal yang tertulis adalah Rp. $30.000,00$ per peristiwa Nikah, baik di dalam balai nikah KUA maupun di luar balai nikah KUA. Kemudian direvisi menjadi PP Nomor 48 Tahun 2014 yang menggratiskan biaya pelayanan pencatatan nikah apabila masyarakat bersedia melangsungkan proses pernikahannya di dalam balai nikah yang dimiliki masing-masing KUA. Sementara masyarakat akan dikenakan biaya sebesar Rp. 600.000,00 apabila menghendaki agar pernikahannya dilangsungkan di luar balai nikah yang dimiliki KUA dan di luar jam kerja KUA.

Biaya tersebut sebenarnya disetorkan langsung pada rekening bank Negara yang telah ditunjuk. Namun berdasarkan hasil penelitian yang telah dilakukan, peneliti menemukan masih ada masyarakat yang menyerahkan biaya pembayaran pelayanan tersebut kepada RT/P3N setempat. Selanjutnya peneliti juga menemukan bahwajumlah pernikahan yang terjadi setelah adanya upaya pemerintah untuk menarik minat masyarakat untuk menikah di balai nikah KUA dengan cara menggratiskan biaya pencatatan nikah.Apabila proses pencatatan nikah tersebut dilaksanakan di balai nikah mengalami perubahan. Namun belum cukup efektif dikarenakan masih cukup tingginya minat masyarakat untuk melangsungkan pencatatan nikahnya di luar balai nikah KUA.Kemudian selebihnya untuk pelayanan pencatatan nikah yang dilangsungkan didalam balai 
nikah KUA sudah sesuai dengan yang tertulis pada PP Nomor 48 Tahun 2014.

\section{Produk Pelayanan}

Produk pelayanan merupakan hasil yang diterima oleh masyarakat. Dalam pelayanan pencatatan nikah terdapat 2 produk yang dihasilkan dari pelayanan tersebut yaitu akta nikah dan buku nikah (kutipan akta nikah). Produk pelayanan pencatatan nikah berfungsi sebagai alat bukti tertulis yang sah secara hukum Negara adanya pernikahan antara suami dan istri. Fungsi adanya buku nikah itu sangat penting bagi kelanjutan pembuatan surat-surat lainnya seperti pembuatan Kartu Keluarga (KK), Akta Kelahiran untuk anak, dan lain-lain. Apabila buku nikah yang diserahkan kepada masyarakat yang telah melangsungkan pernikahan tersebut hilang maka dapat diajukan permohonan untuk penerbitan salinan buku nikah.Berdasarkan hasil penelitian di KUA Kecamatan, buku nikah yang sudah diserahkan kepada masyarakat dalam keadaan baik dan layak juga sudah sesuai dengan Surat Edaran Dirjen Bimas Islam dan Urusan Haji No.DJ.1/I/PW.01/1487/2005 tentang Petunjuk Pengisian Formulir Nikah Rujuk.Tidak terdapat kesalahan cetak atau tulis dalam akta nikah maupun buku nikahnya.

\section{Sarana dan Prasarana}

Salah satu faktor utama yang dapat mempengaruhi kualitas dari pelayanan publik adalah adanya sarana prasarana. Adanya sarana dan prasarana yang memadai dapat membantu untuk menunjang dan meningkatkan proses pelayanan publik yang diberikan oleh suatu instansi. Berdasarkan hasil pengamatan di lapangan, hampir setiap KUA tidak ada fasilitas khusus untuk gedung Balai nikah di KUA, walaupun KUA tersebut termasuk dalam tipologi A. Untuk acara pernikahan atau pun suscatin masih menggunakan ruangan KUA.Tempat yang terbatas menjadi alasan klasik, tak jarang Balai Nikah harus berhimpitan dengan berbagai arsip dan berkas perkawinan.Bahkan disebagianKUABalaiNikahharusbergantian dengan ruang staf KUA itu sendiri. Sehingga bagaimana mungkin hal itu bisa menghasilkan output yang baik ditengah antusiasme masyarakat.Namunada juga sebagian KUA Kecamatan yang sudah cukup memiliki sarana dan prasarana yang baik, dalam hal pelayanan pencatatan nikah,seperti diketahui di KUA Jati Agung, KUA Merbau Mataram.Sarana dan prasarana pendukung yang dimiliki oleh
KUA Kecamatan meliputi adanya bangunan KUA dengan halaman yang cukup, ruang tunggu yang nyaman, ruang Kepala KUA dan alat perkantoran yang cukup memadai.

\section{Kompetensi Pemberi Pelayanan Publik}

Kompetensi pemberi pelayanan publik ini dilakukan sesuai dengan kemampuannya, yaitu harus berdasarkanpengetahuan, keahlian, keterampilan, sikap dan perilaku yang dibutuhkan. Kompetensi petugas pemberi pelayanan publik ini turut menunjang kemaksimalan dalam proses pelayanan. Dalam proses pelayanan pencatatan nikah, petugas KUA sudah bertindak secara professional dengan memberikan pelayanan yang sigap dan ramah kepada masyarakat yang akan mendaftarkan nikahnya. Berdasarkan hasil penelitian banyak masyarakat penerima layanan pencatatan nikah yang merasa puas dengan kinerja dari petugas KUA.Dengan sigapnya membantu masyarakat dalam proses pelayanan pencatatan nikah dari awal pendaftaran sampai akad nikah dilangsungkan.

Dalam hal ini perubahan mindset pelayanan di KUA telah dibangun, Reformasi birokrasipun sedang dilaksanakan. Banyak pihak tentunya berharap KUA dengan wajah baru dalam pelayanan akan memberikan kesan mendalam dimasyarakat. Karena salah satu indikator keberhasilan dalam bidang pelayanan adalah Indeks Kepuasan Masyarakat (IKM) yang telah mendapat pelayanan. Namun perlu disadari, bahwa proses ini baru berjalan, dan diupayakan akan terus berubah menuju kondisi yang lebih baik dan ideal. Jika semua potensi masalah tersebut dapat ditangani dengan segera, maka bukan hal yang tidak mungkin KUA akan menjadi pelayan publik yang profesional, transparan, dan akuntabel.

Namun dalam hal pelayanan pencatatan nikah di KUA terkait dengan jumlah SDM di KUA, sebagian KUA sudah sesuai dengan kebutuhan standar pelayanan, seperti diketahui di KUA Natar ada 13 orang pegawai termasuk 3 orang penghulu, kemudian KUA Jati Agung, dan KUA Merbau Mataram dengan dibantu oleh sejumlah P3N. Sebagian KUA yang lainnya masih diperlukan SDM di KUA, seperti KUA Tanjung Sari dan KUA Rajabasa, tidak ada tenaga penghulunya.Persoalan yang dihadapi dalam pelayanan pencatatan Nikah baik di KUA maupun di luar KUA, yaitu pada saat musim-musim tertentu seperti saat musim nikah yang sering terjadi pada bulan Oktober (bulan pasca haji).Terkadang ada catin yang kurang berkenan 
karena tidak bisa mendapatkan pelayanan sesuai dengan waktu yang diinginkan.Karena harus menyesuaikan waktu dengan catin lain yang lebih dahulu mendaftar untuk mendapatkan pelayanan pencatatan nikah. Di samping itu terkendala dengan jarak tempuh dari desa satu ke desa yang lainnya dalam penentuan waktu bagi kehendak nikah, dan terkadang waktunya bersamaan dalam pendaftaran kehendak nikah.

\section{Faktor penghambat}

Pemberian pelayanan kepada masyarakat secara optimal, hampir sebagian besar KUA masih memiliki keterbatasan sarana maupun sarana penunjang kegiatan. Beberapa hambatan yang dihadapi selama pelaksanaan proses kerja antara lain :

1. Terbatasnya jumlah ruangan yang ada di KUA, sedangkan kegiatan pelayanan publik yang dilakukan telah bertambah dengan adanya pemberian kursus bagi calon pengantin yang diadakan dua kali dalam satu minggu.

2. Tidak adanya kendaraan operasional dalam menunjang mobilitas kegiatan dan pembinaan di daerah-daerah.

3. Sarana komunikasiyang belum tersedia terutama di daerah-daerah terpencil dalam wilayah kerja, seperti di KUA Kecamatan Rajabasa.

4. Minimnya sarana penunjang kerja seperti lemari arsip, AC dan lain-lain.

5. Keterbatasan tenaga SDM sebagai penghulu, dan tenaga teknis maupun tenaga administrasi dalam kompetensi kerja yang ideal.

\section{Upaya Pemecahannya}

Walaupun masih terdapat hambatanhambatan teknis maupun non teknis dalam pelaksanaan kerja pada KUA, hal ini tidak menutup kemungkinan upaya untuk mengoptimalisasikan pemberian pelayanan kepada masyarakat.Hubungan dan kerjasama dengan pihak-pihak terkait tetap dilaksanakan secara berkesinambungan dalam mengatasi permasalahan yang timbul. Sedangkan upaya-upaya perbaikan dan pembenahan dalam upaya pemecahan masalah yang telah dilakukan antara lain :

1. Memberdayakan ruangan kerja yang ada dengan system pergantian penggunaan ruangan. Saat kegiatan pembinaan atau rapat kerja maka ruang kerja staf TU dipindahkan sementara ke ruangan penyuluh. Setelah kegiatan selesai maka staf TU kembali ke ruangan.

2. Dalam melakukan kunjungan kerja di daerah- daerah, koordinasi dengan instansi dan lembaga terkait, serta kegiatan-kegiatan lain yang memerlukan alat transportasi. Pada umumnya pihak KUA (Penghulu/Kepala KUA) dengan menggunakan kendaraan pribadi dengan biaya sendiri. Sedangkan dalam menginput datadata kependudukan di daerah yang diperlukan secara berkala dan berkesinambungan, pada umumnya KUA menggunakan laporan dari para Kades dan tokoh masyarakat yang memang relatif menguasai keadaan daerah di mana mereka berdomisili.

3

4. Penggunaan sarana komunikasi dalam menunjang kinerja kerja sehari-hari, memanfaatkan alat komunikasi milik pribadi terutama komunikasi dalam bentuk percakapan maupun dalam bentuk pesan. Sedangkan komunikasi dalam bentuk fax dan internet, KUA Kecamatan menggunakan jasa rental yang tersedia di wilayah kerja KUA.

5. Penyimpanan dokumen dan arsip penting lainnya tetap menggunakan lemari penyimpanan yang ada dengan mengadakan perbaikan lemari dan meja seperlunya. Untuk mengatasi resiko tercecer, hilang atau rusaknya dokumen dan arsip penting lainnya. Sedangkan kursi kerja/kursi tamu secara bertahap ditambah dan dibiayai secara kolektif oleh bidang Kasi Pemberdayaan KUA Provinsi.

6. Staf dan tenaga teknis yang ada selalu diberikan pengarahan secararutin, danberkesinambungan. Agar tetap mampu dan cakap untuk mengatasi permasalahan yang timbul dengan tetap dalam pengawasan Kepala KUA. Adapun pelatihan dan pembinaan yang diadakan oleh Kementerian Agama atau instansi lain dalam meningkatkan wawasan dan pengetahuan aparatur, selalu siap diikutsertakan selama tidak mengganggu proses pelayanan kepada masyarakat.

\section{PENUTUP}

Terkait telah terbitnya PP 48 Tahun 2014, setidaknya ada tiga hal baru yang akan mendapat perhatian KUA dalam pelayanan publiknya.

Pertama, meminimalisir penyimpangan keuangan. Sebagaimana akan diatur dalam PMA tentang pengelolaan PNBP NR, bahwa pembayaran NR di luar kantor oleh Catin harus melalui bank yang ditetapkan oleh Sekjen, yaitu Bank BRI, BNI, Mandiri, dan BTN. Ini merupakan cara baru pembayaran, dimana uang tidak diterimakan kepada 
petugas KUA. Dengan cara ini maka kemungkinan "penyimpangan" dapat diminimalisir. Tentu peluangnya masih terbuka namun setidaknya orang berfikir dua kali untuk melakukannya.Demikian juga bagi masyarakat, biaya nikah yang diumumkan secara transparan melalui banner-banner Zona Integritas dan dibayarkan melalui bank, setidaknya akan memulihkan kepercayaan publik bahwa KUA tidak "main-main" lagi dengan biaya NR. Jika masih ada oknum yang nekat, masyarakat dapat dengan mudah mengajukan komplain atau membawa ke ranah hukum.

Kedua, layanan nikah sejatinya gratis. Untuk layanan pernikahan di kantor sama sekali tidak dikenakan biaya (gratis), baik bagi keluarga miskin, maupun kaya. Yang penting, nikah dilaksanakan di kantor KUA. Demikian juga nikah di luar kantor juga sejatinya gratis, hanya saja dikenakan biaya sebesar Rp 600 ribu bukan sebagai pembayaran biaya pencatatan nikahnya.Namun sebagai pengganti transportasi dan jasa profesi bagi penghulu yang menikahkan di luar kantor dan di luar jam kerja. Dari aspek ini pencatatan nikahnya tetap gratis atas dasar Undang-undang yang mengatur tentang kependudukan yang tidak membolehkan pungutan biaya kepada publik.Kebijakan ini sesungguhnya sebagai terobosan penting, dimana pemerintah memberikan layanan publik secara cuma-cuma. Melalui layanan free ini maka citra pemerintah akan semakin baik di mata publik.

Ketiga, modernisasi layanan berbasis IT.Seiring dengan tekad Bimas Islam yang ingin meningkatkan pelayanan di KUA melalui SIMBI, khususnya Sistem Informasi Manajemen Nikah (SIMKAH), dengan pola pembayaran melalui setor bank.Maka dalam hal ini pembayaran dapat diintegrasikan dengan aplikasi SIMKAH secara real-time (online). Jika seluruh jaringan SIMKAH di Indonesia telah terhubung dengan sistem perbankan penerima setoran PNBP NR yang ditetapkan Sekjen Kemenag, maka KUA telah bermetamorfosis menjadi lembaga pelayanan publik yang modern.

Ketiga hal tersebut merupakan wajah baru layanan KUA pasca terbitnya PP Nomor 48 Tahun 2014 yang mengarah pada upaya peningkatan kinerja melalui: (a) pelaksanaan pakta integritas untuk menghindari penyimpangan atas biaya pernikahan; (b) penyediaan layanan publik KUA secara gratis dan terbuka, berasaskan persamaan hak masyarakat; dan (c) transparansi pengelolaan dana PNBP NR yang terhubung melalui teknologi informasi.Melalui terbitnya PP Nomor 48 Tahun
2014 ini, maka wajah baru layanan KUA ke depan akan semakin amanah dan profesional dengan motto utama Kementerian Agama, "Ikhlas Beramal".

Dengan demikian :Program kerja dan kegiatan yang dilaksanakan oleh KUA di Kabupaten Lampung Selatan, telah berjalan sesuai dengan rencana yang telah disusun sebelumnya. Dengan tetap mengacu pada SK Kepala Kanwil Kemenag Provinsi Lampung No.Wh.II/Ins/05/1990 tanggal 01 Mei 1990, tentang fungsi dan tugas pokok KUA.Koordinasi dan kerjasama lintas sektoral dengan instansi dan lembaga terkait dalam wilayah Kecamatan khususnya, dan wilayah Kabupaten Lampung Selatan pada umumnya, telah mengalami peningkatan signifikan.Untuk memberikan pelayanan dan penyelesaian terhadap semakin kompleksnya permasalahan yang timbul di masyarakat.Namun untuk mengatasi persoalan di masyarakat memerlukan waktu yang lebih lama.

Keempat; Keberagaman etnis dan suku pada masyarakat yang berdomisili, khususnya di wilayah lingkungan KUA Kecamatan Kabupaten Lampung Selatan, dapat memberikan metode dan cara pendekatan secara cultural dalam mengambil langkah-langkah penyelesaian permasalahan. Hal ini terkait dengan masalah kebiasaan dan adat istiadat yang berbeda antar etnis dan suku tersebut dalam menyelesaikan suatu persoalan.KUA dilihat dari Tipologinya (A B C D) yaitu berdasarkan pada jumlah peristiwa nikah dan rujuk dan tingkat kesulitan wilayah geografis. Hal lain yang dapat mempengaruhi terhadap perubahan tipologi, karena dilihat dari jumlah peristiwa nikah dan dilihat dari pemekaran wilayah Kecamatan.

\section{UCAPAN TERIMA KASIH}

Puji Syukur senantiasa tercurahkan kepada Illahi Rabbi, Sholawat dan salam selalu terlimpahkan pada junjungan Nabi Besar Muhammad SAW. Atas Rahmat dan Inayahnya Al-hamdulillah dalam kesempatan ini penulis dapat menyelesaikan Naskah KTI, yang dikutip dari Lporan Hasil Penelitiandi Lampung. Selesainya penulisan Naskah ini tidak lepas adaya dukungan dari berbagai pihak terkait, baik dukungan secara moril maupun materil. Untuk itu tak lupa penulis ucapkan terima kasih kepada :

- Kepala Balai Litbang Agama Jakarta beserta seluruh jajarannya, Struktural dan pelaksana (TU BLAJ) yang telah memfasilitasi kelancaran dalam proses penelitian ini.

- Kasi Pemberdayaan KUA Kanwil Provinsi 
Lampung, Kasi Kepenghuluan, dan Kasi Urais, yang telah meluangkan waktunya sebagai informan dalam penelitian ini.

- Kepala Kemenag dan Kasi Bimas Islam Kabupaten Lampung Selatan, dan stafnya.

- Kepala KUA Kecamatan Natar beserta stafnya, KUA Merbau Mataram, KUA Tanjung Sari, dan KUA Rajabasa, yang telah memberikan informasi dalam pengumpulan data penelitian.

- Tim Redaksi/ Riviuer yang telah berusaha untuk perbaikan penyempurnaan penulisan Naskah KTI ini.

Semoga Allah SWT membalas atas segala kebaikan dan kesalehan sosial yang telah diberikan.

\section{DAFTAR PUSTAKA}

A.S. Moenir. 2010. Manajemen Pelayanan Umum di Indonesia Jakarta: Pembaruan Aksara Danim, Sudarwan.

Alfabeta Tanzeh, Ahmad 2009. Metode Penelitian Administrasi Bandung

Abdullah, Abdul Gani. 1994. Pengantar Kompilasi Hukum Islam dalam Tata Hukum Indonesia, Gema Insani PressJakarta

Al Munawar, Husin, Said Agil. 2004. Hukum Islam dan Pluralitas Sosial, PenamadaniJakarta

Bisri, Cik Hasan 2003.Peradilan Agama di Indonesia, Raja Grafindo PersadaJakarta

Djazuli, A 1991. Ilmu Fiqh: Sebuah Pengantar, Orba Sakti,Bandung

Hasan, KN, Sofyan 1994. Dasar-Dasar Memahami Hukum Islam di Indonesia, Usaha NasionalSurabaya

H. Hadari 2002. Instrumen Penelitian Bidang Sosial,Gava Media Nawawi Yogyakarta

Kuntowijoyo 1991.Paradigma Islam, MizanBandung.

Lukito, Ratno 1998. Pergumulan Antara Hukum Islam dan Adat di Indonesia, INISJakarta.

Lilian Poltak,2008.Manajemen Pelayanan: Pustaka Pelajar Sinambela, Yogyakarta

Moleong, Lexy, J. 2007. Transformasi Pelayanan Publik Pembaruan Jakarta.

Mubarok, Jaih 2000. Sejarah dan Perkembangan Hukum Islam, Remaja Rosdakarya,Bandung

Napitupulu, Paimin 2007.Metodologi Penelitian Kualitatif PT. Remaja Rosda Karya Bandung
Sugiyono 2010.Reformasi Pelayanan Publik,Teori, Kebijkan, dan Implementasi PT. Bumi Aksara Jakarta

Sismono 1991.Sejarah dan Amal Bakti Departemen Agama Republik Indonesia, Bina SiswaBandung

Syarifuddin, Amir 2002. Meretas Kebekuan Ijtihad: Isu-isu Penting Hukum Islam Kontemporer di Indonesia, Ciputat PressJakarta

Sumber Perundang-undangan Nomor 1 Tahun 1974 tentang Perkawinan.

Peraturan Pemerintah Nomor 9 Tahun 1975 tentang Pelaksanaan Undang-Undang Nomor 1 Tahun 1974 tentang Perkawinan

Peraturan Menteri Agama Nomor 11 Tahun 2007 tentang Pencatatan Nikah

Peraturan Menteri Agama Nomor 11 Tahun 2007 tentang Kewajiban PPN

Peraturan Pemerintah Nomor 48 Tahun 2014 tentang perubahan atas peraturan pemerintah nomor 47 tahun 2004 tentang tarif atas jenis penerimaan Negara bukan pajak yang berlaku pada departemen agama.

Undang-Undang Nomor 25 Tahun 2009 tentang Pelayanan Publik.

Keputusan Menteri Negara Aparatur Negara No 25 Tahun 2004 tentang Pedoman Umum Penyusunan Indeks Kepuasan Masyarakat Unit Pelayanan Instansi Pemerintah.

Keputusan Menteri Negara Aparatur Negara No. 63 Tahun 2003 tentang Pedoman Umum Penyelenggaraan Pelayanan Publik

UU Nomor 22 Tahun 1946 tentang Pencatatan Nikah, Talak, dan Rujuk

Kabupaten Lampung Selatan Dalam Angka 2013. BPS Kabupaten Lampung Selatan. 2013. p. 43. ISSN 0215-4072.

Sumber Website :

http://bimasislam.kemenag.go.id/post/opini/wajahbaru-layanan-kua-pasca-terbitnya-pp-48-tahun2014\#sthash.w2chpbJA.dpuf

h t t p : / / w w w. k e m e n a g. go.id / i n d e x . php?a=berita\&id=173515 http://www.tempo.co/ $\mathrm{read} / \mathrm{news} / 2013 / 12 / 05 / 058535032 /$ Forum-KUAJatim-Hadiri-Sidang

http://lampungpost.com/ruwa-jurai/20048lambang-daerah-2012-logo-baru-lamselterpajang-di-randis.html. 